\title{
Review of $\mathbf{4 0}$ years of research carried out in Serbia on sunflower pollination
}

\author{
Sreten Terzić ${ }^{1, *}$, Vladimir Miklič ${ }^{1}$ and Petar Čanak ${ }^{2}$ \\ ${ }^{1}$ Institute of Field and Vegetable Crops (Industrial crops department), Maksima Gorkog30, 21000 Novi Sad, Serbia \\ ${ }^{2}$ Institute of Field and Vegetable Crops (Maize department), Maksima Gorkog30, 21000 Novi Sad, Serbia
}

Received 2 May 2017 - Accepted 6 October 2017

\begin{abstract}
Sunflower pollination has been a subject of research for more than 40 years at the Institute of Field and Vegetable Crops in Novi Sad, Serbia. Since the first experiments in 1970s, the importance of climatic conditions was acknowledged and analyzed as a key factor for the performance of plants and pollinators. Climatic conditions, disease and pest problems changed significantly during this period, but sunflower production technology and breeding also advanced making seed production more stable. Nonetheless, the quality of agronomic practices still varies which also reflects on the plant and pollinator performance. Sunflower breeding led to improved germplasm which still maintains high degree of variability for nectar content and pollinator attractivity. Pollinators are essential in crosses involving cytoplasmic male sterile lines, but are also beneficial in hybrid sunflower seed production. Pollinator attractivity is thus an important trait for both breeders and producers and worth to be considered as a quality trait in sunflower breeding programs.
\end{abstract}

Keywords: sunflower / pollination / honey bee / Serbia

Résumé - Retour sur $\mathbf{4 0}$ années de recherche menées en Serbie sur la pollinisation du tournesol. La pollinisation du tournesol est l'objet de travaux de recherche depuis plus de 40 ans à l'Institut des cultures de plein champ et des cultures légumières de Novi Sad, en Serbie. Depuis les premières expériences conduites dans les années 1970, l'importance des conditions climatiques a été reconnue et analysée comme un facteur clé de la performance des plantes et des insectes pollinisateurs. Les conditions climatiques, les problèmes de maladies et de ravageurs ont considérablement changé au cours de cette période, mais les techniques de production et la sélection du tournesol ont également progressé, ce qui a permis de stabiliser la production de semences. Néanmoins, la qualité des pratiques agronomiques reste encore fluctuante, influant également sur la performance des plantes et celle des insectes pollinisateurs. La sélection du tournesol a conduit à l'amélioration du matériel génétique, qui possède encore un haut degré de variabilité vis-à-vis de la production de nectar et l'attractivité des insectes pollinisateurs. Les insectes pollinisateurs s'avèrent essentiels dans les croisements impliquant des lignées à stérilité mâle cytoplasmique, mais également bénéfiques dans la production de semences hybrides de tournesol. L'attractivité des insectes pollinisateurs représente un caractère important à la fois pour les sélectionneurs et les producteurs et devrait être considérée comme un critère de sélection dans les programmes d'amélioration génétique.

Mots clés : tournesol / pollinisation / abeille domestique / Serbie

\section{Introduction}

The first significant increases in sunflower production in Serbia began in the 1930s and culminated with the introduction of Russian high-oil varieties in the 1960s. After the discovery of cytoplasmic male sterility and the first restorer genes,

\footnotetext{
*Correspondence: sreten.terzic@nsseme.com
}

sunflower hybrids replaced varieties in production and sunflower has since been grown on 140000 to 220000 ha in Serbia, $90 \%$ of which in Vojvodina province. Sunflower is not only a source of oil, but also an important melliferous plant. Owing to the amount of nectar and pollen it produces, it is one of the most important bees pasture in Serbia. On the other hand, honey bee is the most important pollinator of sunflower, as it performs $50-90 \%$ of pollination depending on climatic conditions (Miklič, 1996). The change from open pollinated 
Table 1. Different field trials on sunflower pollination, setup at Rimski šančevi - Novi Sad (or otherwise stated location in trial type section) and their respective duration, subject, type, material and reference.

\begin{tabular}{|c|c|c|c|c|}
\hline Duration & Subject & Trial type & Material & Reference \\
\hline 1985 & $\begin{array}{l}\text { Sunflower autofertility and } \\
\text { fertilization in open pollination }\end{array}$ & Research trial & 5 hybrids & $\begin{array}{l}\text { Marinković and Škorić } \\
\text { (1986) }\end{array}$ \\
\hline 1990-1991 & $\begin{array}{l}\text { Effect of environment and } \\
\text { genotype on insect visitation }\end{array}$ & MSc research trial & $\begin{array}{l}3 \text { CMS lines; } 3 \text { B lines } \\
3 \text { Rf lines; } 3 \text { hybrids }\end{array}$ & Miklič (1992) \\
\hline 1990-1991 & $\begin{array}{l}\text { Honeybees for inter-pollination } \\
\text { of wild sunflower species }\end{array}$ & Research trial & $\begin{array}{l}11 \mathrm{H} . \text { annuus } \\
6 \mathrm{H} . \text { petiolaris }\end{array}$ & Dozet et al. (1993) \\
\hline 1996 & $\begin{array}{l}\text { Inflorescence characteristics and } \\
\text { seed yield of sunflower }\end{array}$ & Research trial & 5 B lines; 4 Rf lines & Atlagić et al. (2000) \\
\hline 2000-2002 & $\begin{array}{l}\text { Disc flower corolla length and } \\
\text { nectar content; } \\
\text { pollination conditions and yield }\end{array}$ & Long-term trial & $\begin{array}{l}4 \text { B lines; } 4 \text { Rf lines } \\
4 \text { hybrids }\end{array}$ & $\begin{array}{l}\text { Atlagić et al. (2003); } \\
\text { Miklič et al. (2003); } \\
\text { Joksimović et al. (2005) }\end{array}$ \\
\hline $\begin{array}{l}2002,2003,2005- \\
2008,2010\end{array}$ & $\begin{array}{l}\text { Monitoring of nectar production } \\
\text { of current and experimental } \\
\text { hybrids }\end{array}$ & $\begin{array}{l}\text { Research and production } \\
\text { trials }\end{array}$ & 10 hybrids per trial & Table 3 \\
\hline 2007 & $\begin{array}{l}\text { Influence of pollination method } \\
\text { on sunflower yield }\end{array}$ & Research trial & $\begin{array}{l}3 \text { CMS lines; } 3 \text { B lines } \\
3 \text { Rf lines; } 3 \text { hybrids }\end{array}$ & $\begin{array}{l}\text { Terzić et al. (2008); } \\
\text { (2010a) }\end{array}$ \\
\hline 2008 & $\begin{array}{l}\text { Insecticide seed treatment and } \\
\text { insect visitation }\end{array}$ & Research trial & 1 hybrid & Terzić et al. (2010b) \\
\hline 2010-2012 & $\begin{array}{l}\text { Sunflower fertilization under } \\
\text { variable ecological conditions }\end{array}$ & PhD research trial & $\begin{array}{l}10 \text { CMS lines; } 10 \text { B lines } \\
5 \text { Rf lines; } 5 \text { hybrids }\end{array}$ & Čanak (2014) \\
\hline
\end{tabular}

varieties to hybrid sunflower production increased the need for adequate pollination as the transfer of pollen is necessary to obtain seed in crosses involving cytoplasmatically male sterile (CMS) plants. In the late 1970 s, a research program was started with the goal to elucidate the factors that affect the complex interaction between sunflower and honey bees as the most frequent pollinator. The current paper is a review of research studies conducted independently from one another over the last decades (Tab. 1). The most significant results covering the effect of environment, agricultural practices, plant breeding as well as the influence of various factors on pollinator attractivity are presented.

\section{Environment}

Stressful climatic conditions as well as inappropriate agricultural practices inhibit plant growth and also lower the nectar production. The influence of plant genotype was found to be less significant than environment for nectar production and attractivity to pollinators, while fertilization was also limited by stressful climatic conditions (Jocić, 2000; Miklič et al., 2002). Honey bee pollination efficiency can, on the other hand, also be affected substantially by frequent relocations, food quality, parasites and pesticides, which lower colony strength (Goulson et al., 2015). The influence of individual climatic variables also depends on their interaction. High air temperature and low relative air humidity were found to negatively affect pollination (Golubović et al., 1992), similarly to observations made in the USA (Smith, 1978).

The most important climatic factors were found to be precipitation, air humidity and temperature, while wind can lead to the reduction in nectar volume making it inaccessible to pollinators (Miklič, 1996).

\subsection{Precipitation}

After the year 2000, extremes in high or low precipitation became more often in Vojvodina and affected not only honey bee activity but also seed yield. Precipitations during flowering decreased pollinator efficiency as well as pollen quality. Pollen is washed from the anthers and deteriorates faster becoming less accessible to pollinators. On the other hand, drought 


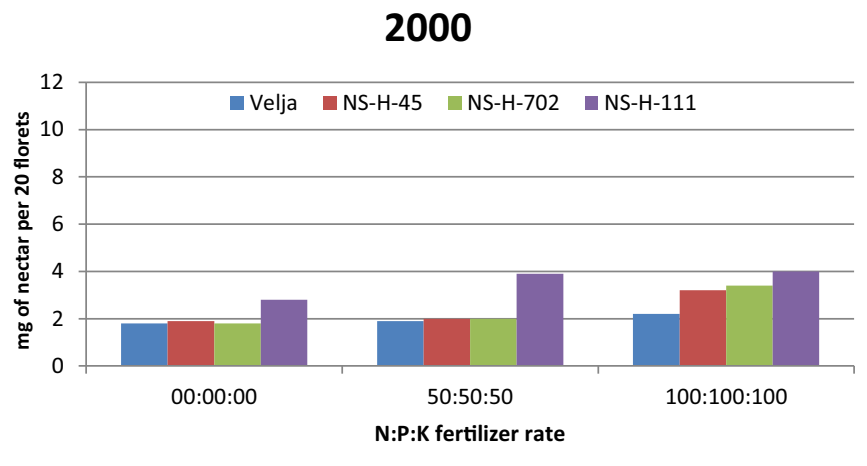

2001

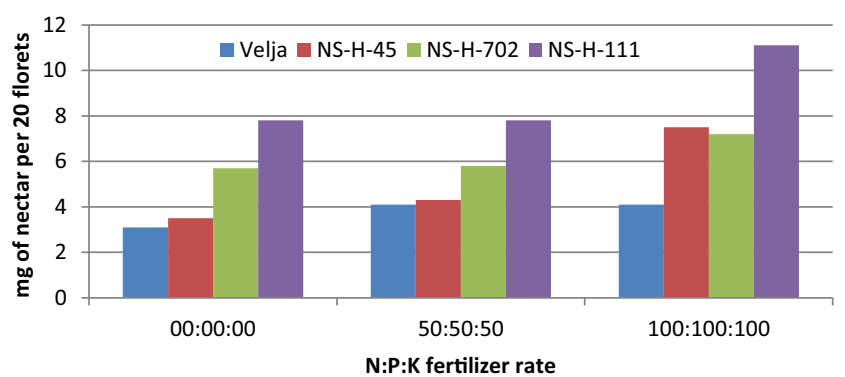

Least significant differences (LSD) between the evaluated hybrids and fertilization rates

\begin{tabular}{ccc}
\hline LSD & Hybrids & Fertiliser \\
\hline 0.05 & 1.2 & 1.04 \\
0.01 & 1.82 & 1.58 \\
\hline
\end{tabular}

Fig. 1. Content of nectar in four sunflower hybrids and three fertilization rates $(0,50$ or $100 \mathrm{~kg})$ evaluated in 2000 and 2001 .

causes lower nectar production which results in lower bee visitation. In the case of long-term drought, the total number of florets per head is decreased and thus the total nectar and pollen volume is also lower (Miklič et al., 2003).

Typical examples of extreme years are 2000 with extremely low precipitation and high temperatures and 2001 with optimal water availability. In extreme soil and air drought conditions, as they were in 2000 , nectar production was limited and ranged between 1.8 and $4 \mathrm{mg}$ per 20 florets. Influence of fertilization rates and genotypes on nectar production was not significant (Fig. 1). On the other hand, in 2001 the influence of both genotypes and fertilization was significant and nectar quantity ranged between 3.1 and $11.1 \mathrm{mg}$ per 20 florets (Miklič et al., 2002; Atlagić et al., 2003).

Soil moisture content was thus found to be the main limiting factor for nectar production and should be considered as a factor when determining sunflower melliferous value (Joksimović et al., 2005).

\subsection{Temperature}

The trend of global warming can also be shown by highest temperatures, where most of the temperature extremes in Serbia in the last 100 years have been recorded in the previous two decades (Tab. 2).
Table 2. Maximum air temperature for various time periods in Serbia (data obtained from Republic hydrometeorologycal service of Serbia).

\begin{tabular}{lll}
\hline Category & Period & Temperature $\left({ }^{\circ} \mathrm{C}\right)$ \\
\hline Month & August 1992 & 26.8 \\
Year & 2000 & 14.1 \\
Summer & 2012 & 25.7 \\
Winter & $1997 / 1998$ & 5.2 \\
April (Sowing time) & 2000 & 16.1 \\
June (Budding) & 2000 & 22.8 \\
Day in July (Flowering) & 24.07 .2007 & 44.9 \\
Day in January & 07.01 .2001 & 20.7 \\
\hline
\end{tabular}

Higher air temperature can negatively affect plant growth by inducing shorter development stages. Large temperature variations were also found to have negative effect on pollination. Temperatures above $27^{\circ} \mathrm{C}$ reduce nectar production, while above $33^{\circ} \mathrm{C}$ it is completely stopped. Highest increase of honey accumulation in hives was registered with daily temperatures of $24-27^{\circ} \mathrm{C}$, morning temperatures of 13 $16^{\circ} \mathrm{C}$ and evening temperatures of $16-20^{\circ} \mathrm{C}$. Low relative humidity $(\mathrm{Rh})$ of $25 \%$ combined with high temperatures has a highly negative effect on nectar production. Such conditions have also adverse effects on honey bee activity, when foraging occurs only in the early morning and evening, while in normal conditions the peak activity is at 9 a.m. and 4 p.m. Depending on the season, optimum conditions during flowering include minimum and maximum temperatures of 10 to $30^{\circ} \mathrm{C}$, with an average temperature range of $22-24^{\circ} \mathrm{C}$, including the minimum and maximum Rh of 55 to $90 \%$ (Jančić and Pap, 1980; Miklič, 1996; Čanak, 2014).

\section{Agricultural practices}

Sunflower is a highly adaptable plant and can be grown in diverse growing conditions. Agricultural practices thus vary, even in smaller regions. This is also due to the fact that sunflower is sown where other crops would not justify the investment because of poor soils and stressful climatic conditions. The more frequent occurrence of stressful climatic conditions increases the importance of proper agricultural practices, which can lower the negative impact on crop. All practices that affect the plant condition can also eventually affect pollen and nectar production (Miklič et al., 2000a, b). Adequate crop rotation with species like wheat and corn as the previous crop should be used instead of monoculture or too short crop rotation cycle to limit the impact of diseases, insects and weeds. Sunflower can tolerate drought better than most other field crops but requires properly prepared soil starting with primary tillage performed in autumn instead of spring. Plant spacing and density depend on the type of hybrid, but more importantly, determine available resources for the plant. A three-year trial was setup at IFVCNS during 2013-2015 to evaluate the effects of sowing density on nectar production. It was found that nectar quantity is decreasing with the increase of plant density from 30000 to 60000 but the higher plant number per hectare compensates the decrease in nectar production (Terzić, unpublished data). 
In a trial where the effect of fertilizer on nectar production was evaluated, the lowest nectar content was found when no fertilizer was applied. With the increase of fertilizer concentration in the soil, all sunflower hybrids had significantly higher nectar production up to the optimal level of 50$100 \mathrm{~kg} /$ ha of N:P:K (Fig. 1). According to the results of the trial, a significant decrease in honey production from sunflower fields in Serbia in the second half of the 1990s can probably be attributed to inappropriate agricultural practices, more specifically the reduction or complete lack of fertilization (Miklič et al., 2002).

Historical data on production technology should also be included when comparing sunflower melliferous value. The use of sunflower varieties implied longer flowering periods with less uniform flowering than hybrids, while older agricultural machines were less efficient resulting with successive sowing that was performed in a significantly longer time period than today. The pollinators thus had more time to collect nectar from the same area than today.

\section{Sunflowers}

The effect of breeding on nectar production is evident according to the historical data and recently published results on honey production in Serbia. During the 1950s when the first NS cultivars were grown (Novosadski 4, 8, 18), honey production averaged at $10 \mathrm{~kg}$ per hive (Jevtić, 1955). With the introduction of higher yielding Russian varieties in 1961, honey production increased to $20 \mathrm{~kg}$ per hive with a daily yield of $3 \mathrm{~kg}$ per hive. First NS hybrids registered in 1978 also brought significant increase in honey yield. The first generation of hybrids (NS-H-62-RM, NS-H-63-RM, NS-H-65-RM) increased the yield per hive up to $67 \mathrm{~kg}$, while the second, starting from 1984 (NS-H-15, NS-H-17, NS-H-43, NS-H-45), continued the same trend with yields of up to $66 \mathrm{~kg}$ per hive. Such results are also registered with modern hybrids, but only in optimal climatic conditions for plant development. On average, a single honey bee society produces $10-35 \mathrm{~kg}$ of honey per hive while foraging on sunflower (Plavša and Nedić, 2015).

A three-year trial (2010-2012) involving CMS (A) lines, male fertile (B) lines, fertility restorer (Rf) lines and hybrids confirmed that autofertility and seed set are more dependent on genotype than year, even though the first two years had optimal water availability and 2012 was characterized by drought. The effect of year was significant for nectar production, pollen vitality and total number of pollinator visits. Nectar production was similar in 2010 and 2011 when averaged on the plant type (A, B, Rf and hybrids) but in drought stress conditions in 2012 Rf lines had lower production than A and B lines, while hybrids performed the best indicating higher adaptability than the inbred lines (Čanak, 2014).

To determine the possible differences between varieties and hybrids and the long-term effects of breeding on nectar production, a trial was performed using a set of four modern hybrids and variety "Peredovik". To limit the influence of climatic factors, the trial was also set in a climate chamber. Peredovik had an average nectar content of the five analysed genotypes in the field and second lowest in controlled conditions (Čanak, unpublished data).
Sunflower is a typical cross-pollinated species, which can tolerate a certain degree of self-pollination. The degree of tolerance mostly depends on genetic factors but also the environment (Marinković and Škorić, 1986). After the discovery of cytoplasmic male sterility by Leclercq in 1966, inbred line production implied considering self-fertility as a positive trait so that today, most of the hybrids can produce seeds even without pollinators. Nonetheless, the use of pollinators is necessary because self-fertility can be even lower than 20\% (Čanak, 2014).

\section{Nectar production}

Pollinator preferences are influenced by many factors, out of which nectar quantity and quality are among the main components. Nectar can be accessed by several methods like capillary tubes, volumetric centrifugation, filter paper strips, flushing of water into the corolla or floating the flowers inverted in water depending on flower structure but the overall conclusion is that no single method can be considered satisfactory for all plant species (Mesquida et al., 1988).

The capillary method has been used on sunflower (PhamDelegue et al., 1985) but it has also been described as unsuitable for collecting nectar amounts less than $1 \mu \mathrm{L}$ and to cause damage to the nectary tissue (McKenna and Thomson, 1988). The appropriate outer diameter of the capillary tubes reduces the risk of tissue damage and allows more precise collecting so that the capillary method was found preferable to others for sunflower nectar collecting at IFVCNS (Sakač et al., 2008).

Florets have significantly higher nectar production on the first day of flowering in comparison to the second and third, which is why it is recommended for honey bee keepers to bring hives before the start of flowering. The production of nectar varies depending on the position of the floret on the sunflower head but not significantly, while in controlled conditions the produced nectar volume is often significantly lower than in the field regardless of genotype (Čanak, unpublished data). Influence of environment on nectar production has been confirmed in several studies where air temperature and humidity were found to have largest effect together with the genotype (Atlagić et al., 2003; Joksimović et al., 2003).

Constant evaluation of hybrids from the IFVC sunflower breeding program provided valuable information on the effect of genotype and environment. Both factors considerably influenced nectar production as presented for selected hybrids in the period of 2002-2010 (Tab. 3).

The largest variation in nectar production was caused by growing conditions, as most of the hybrids varied significantly, while hybrids Velja and NS-H-111 had largest nectar content ranges of 2.5-14.9 and 3.7-15 mg/10 florets, respectively. The influence of genotype on nectar production was also quite large with lowest in hybrid Krajišnik producing an average of 4.2 and Rimi the highest with $11.5 \mathrm{mg}$ of nectar/ 10 florets (Tab. 3).

Trials performed by Atlagic et al. (2003) showed that the inheritance of nectar production in sunflower is under partial or full dominance of the parent with lower nectar production. One of the hybrids exhibited negative heterosis, having lower nectar production than both parents. The trial pointed that 
Table 3. Variability in nectar production influenced by genotype (15 IFVC sunflower hybrids) and environment (various trials in the period from 2002 to 2010 setup at Rimski šančevi - Novi Sad) presented as mg of nectar in 10 florets.

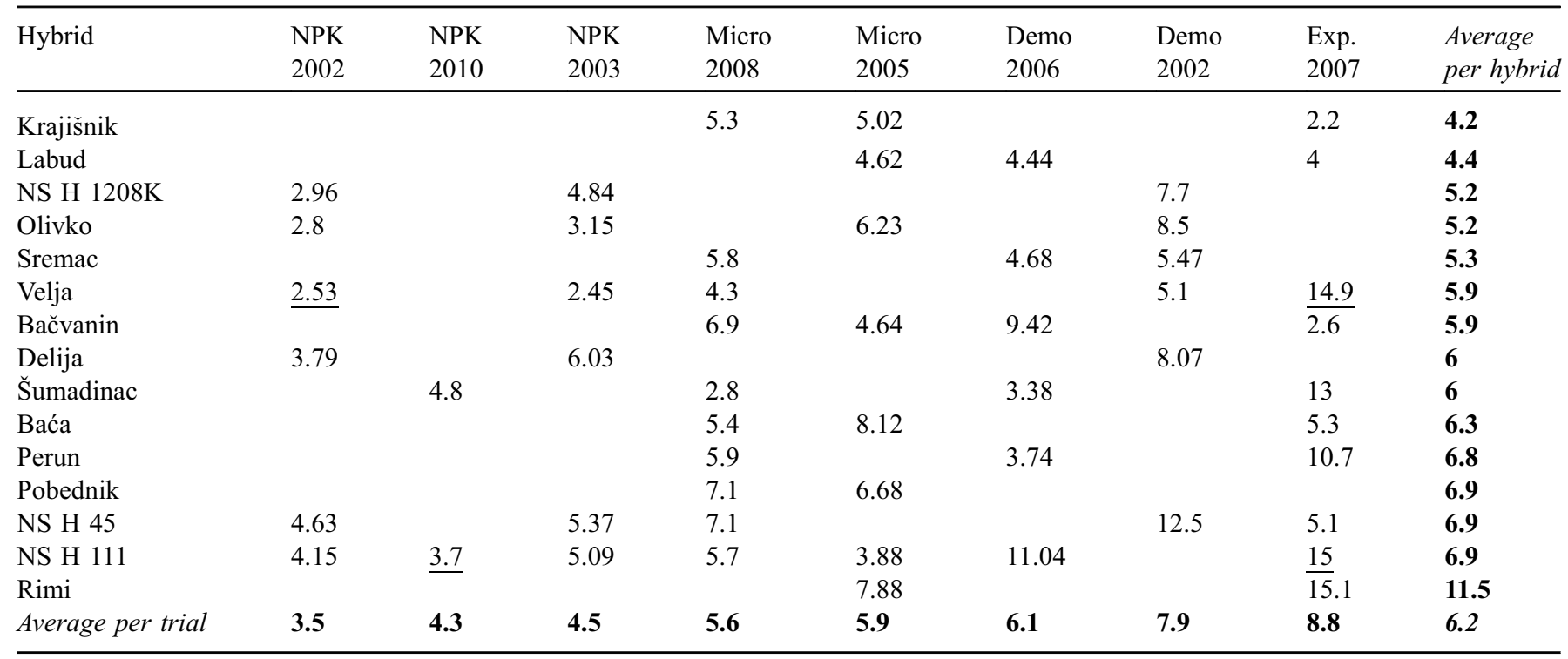

Underlined values represent minimum and maximum values for hybrids with largest nectar production variation.

breeding for higher nectar content is possible by creating parental inbred lines with increased nectar production.

\section{Pollen production and transfer}

Pollen is an important factor of attractiveness to pollinators even though pollen production is not correlated to nectar production (Vear et al., 1990). Similar to those observations, it was also found that nectar content can be in significant negative correlation with pollen viability (Joksimović et al., 2005). Cultivated sunflower usually has above $90 \%$ of viable pollen grains but extremely low or high temperatures can significantly lower viability. More than $50 \%$ of pollen under direct exposure to sunlight for more than 10 hours is not capable of fertilization (Škorić et al., 1989).

Pollen can be stored under low temperatures with minimal loss of viability (Fick and Miller, 1997) but the storage can also eliminate certain gametes and alter population variability in the following generation (Lyakh and Totsky, 2014). Owing to the need to store pollen for crosses where parental lines did not flower simultaneously or interspecific crosses are made, staining methods for pollen viability determination have been developed (Alexander, 1969) and improved for use on sunflower (Atlagić et al., 2012).

The sunflower plants in Vojvodina are mostly visited by honey bees and bumble bees followed by insects from the Syrphidae family and far less butterflies (Miklič, 1996; Čanak, 2014). Managed pollination is performed by bringing honey bee hives to the production field before flowering, while honey bees are also used in smaller isolated plots in breeding programs or for germplasm seed regeneration including wild sunflower species (Dozet et al., 1993; Atlagić and Terzić, 2015). The large size of honey bee colonies often makes them inappropriate for small isolation cages unless "mini nuc" hives are used, but bumble bees were found to be a possible equally efficient alternative (Terzić et al., 2010a).

\section{Sunflower attractivity}

Sunflower produces pollen which is too heavy for wind dispersal (Putt, 1940). Insect pollination is thus beneficial for hybrid seed production, while it is necessary in seed production involving CMS lines. Sunflower attractivity determines the success or failure in the production of hybrid seed as pollen has to be transferred from male fertile to male sterile lines on which the seed is produced (Miklič et al., 2002). Factors that determine attractivity are numerous and include release of volatiles by the flower, ultraviolet reflection of flower parts, stigma color, quality and quantity of pollen and nectar, style length and stigma shape and corolla tube length (Fick and Miller, 1997). Systemic insecticide seed treatment was evaluated as one of the factors that may affect pollinator visit, but no significant difference was found either between the six used insecticides or compared to non-treated control (Terzić et al., 2010b).

Pollinator visitation varies during the day, mainly due to climatic factors, but usually two visitation peaks can be observed. The first is registered after the pollen is released from stamens in the morning and the second in the afternoon after pistil elongation and during increased nectar availability (Miklič, 1992). Pollen availability affected visitation of honey bees and bumble bees differently in a trial where their sunflower pollination efficiency was compared (Terzić et al., 2008). In open pollination where honey bees dominated, the highest number of visits was recorded on hybrids followed by restorer lines and then by $\mathrm{A}$ and $\mathrm{B}$ lines. On the contrary, bumble bees visited $\mathrm{A}$ lines the most, followed by hybrids and then B and restorer lines. Although honey bees collect both nectar and pollen, it has been observed that they can visit flowers for pollen up to 15 times more than for nectar (Free, 1964).

Considering the effect of pollination conditions on fertilization and seed yield in sunflower, it was found that 
quantity of nectar is not significantly correlated to pollinator attractivity (Joksimović et al., 2005; Terzić et al., 2008). However, Miklič et al. (2002) found that visitation does correspond to nectar content and pointed that microclimate has to be considered when determining significance of factors related to visitation. To be more precise, conditions like drought and wind can limit or lower nectar quantity, making nectar collection increasingly difficult for pollinators and thus affecting their preference. On the other hand, optimum water availability can result with pollination conditions where nectar quantity is not affecting preference, so that genotypes with lowest nectar content can have highest visitation (Terzić et al., 2008). The obtained results confirm that the composition of nectar is more important than its quantity for attractivity to pollinators. Sunflower nectar contains approximately the same amounts of glucose and fructose, while sucrose is present in traces, but may be important for pollinator preference. Dry matter content ranges from 45 to $75 \%$ where higher sugar concentration is probably more attractive to pollinators (Vear et al., 1990).

Flower morphology monitoring can be a useful screening method for the study of plant attractiveness to insects. Corolla length of the disk flower is considered as one of the most important components of sunflower attractiveness together with nectar (Atlagić et al., 2003). Shein et al. (1980) found it to be negatively correlated with the number of bee visits which was confirmed with results obtained in Serbia (Golubović et al., 1992; Miklič, 1996; Atlagić et al., 2000). Sammataro et al. (1983) have pointed out that genotypes with disc flower size between 8 and $10 \mathrm{~mm}$ are much more attractive to bees than those whose disc flowers are over $10 \mathrm{~mm}$ in size. A study of IFVC sunflower inbred lines and hybrids showed that mean values of disc flower corolla length ranged between $7.23 \mathrm{~mm}$ and $10.22 \mathrm{~mm}$ (Miklič, 1996). Corolla length should not only be compared with the functional length of the proboscis because honey bees also place part of the head in the floret during nectar collection. Nectar is thus available in most of the flowers, but the increased depth from which the nectar is taken can affect honey bee behavior (Waddington and Herbst, 1987). Considering the genetics of disc flower corolla length, Atlagić et al. (2003) found that incomplete dominance determines inheritance of disc flower corolla length and suggested that development of inbred lines with favorable corolla length is possible. Development of melliferous sunflower cultivars with increased attractivity may be the solution to securing food sources for pollinators, but further studies are necessary to determine which traits are most useful for use in breeding programs (Cerrutti and Pontet, 2016).

\section{Conclusions}

The research on sunflower pollination at IFVCNS is focused on the plant-pollinator interaction mainly evaluating the effects of climatic conditions and the plant genotype. Air temperature and precipitation were found to be the key factors for both plant and pollinator performance.

Modern sunflower breeding programs imply large numbers of crosses for development of inbred lines. They are usually performed in isolation cages, as the first stages of selection are done with a small number of plants. The crosses can be performed manually, but insect pollination may be preferable, as it can provide more efficient pollination together with information on attractivity.

To increase pollinator attractivity through breeding, selection traits would have to be determined so that they are both informative and applicable for large scale evaluation. Owing to demanding methods, some attractivity factors like release of volatiles by the flower were seldom evaluated even though they can determine whether a flower has been visited at all, before the quantity and quality of nectar and pollen can have any effect. Corolla tube length is already used as a trait in some breeding programs, while nectar quality could also be useful for increasing the knowledge on the complex research subject of plant pollinator interactions.

Acknowledgements. The importance of pollinators was acknowledged by Prof. Dragan Škorić, former head of oil crops department and sunflower breeder at IFVCNS, who supported research on sunflower pollination and cooperation with honey bee keepers. The support and active participation in the program was continued by Dr Vladimir Miklič, while many other researchers contributed from different aspects, like MSc Zvonimir Sakač in plant physiology. We also thank our technical assistant Snežana Merdović for her valuable help in nectar extraction and field work. Financial support from IFVCNS and the Ministry of Science and Education of the Republic of Serbia is greatly appreciated as this work was also part of the past National research projects and the current TR31025 project.

\section{References}

Alexander MP. 1969. Differential staining of aborted and non-aborted pollen. Biotech Histochem 44: 117-122.

Atlagić J, Terzić S. 2015. The challenges of maintaining a collection of wild sunflower (Helianthus) species. Genet Resour Crop Evol 63: 1219-1236.

Atlagić J, Joksimović J, Miklič V, Škorić D. 2000. Influence of some inflorescence characteristics on seed yield of sunflower inbred lines. In: Proc. 15th Int. Sunflower Conf, Toulouse, France, pp. E140-144.

Atlagić J, Joksimović J, Sakač Z, Miklič V, Dušanić N. 2003. Mode of inheritance and heritability of disc flower corolla length and nectar content in sunflower. Genetika 35: 59-65.

Atlagić J, Terzić S, Marjanović-Jeromela A. 2012. Staining and fluorescent microscopy methods for pollen viability determination in sunflower and other plant species. Ind Crops Prod 35: $88-91$.

Cerrutti N, Pontet C. 2016. Differential attractiveness of sunflower cultivars to the honey bee Apis mellifera L. OCL 23: D204.

Čanak P. 2014. Seed set efficiency of sunflower genotypes in different ecological conditions. Doctoral Dissertation, Agricultural faculty, University of Belgrade.

Dozet BM, Mandelc S, Škorić D, Farkaš B. 1993. Use of honey bees for controlled interpollination of wild Helianthus annus $\mathrm{L}$, and Helianthus petiolaris ssp. petiolaris Nuttall. Helia 16: 69-76.

Fick GN, Miller JF. 1997. Sunflower breeding. In: Schneiter Albert A, ed. Sunflower Technology and Production. Madison, WI: American Society of Agronomy (ASA), pp. 395-440.

Free JB. 1964. The behaviour of honey bees on sunflowers (Helianthus annuus L.). J Appl Ecol 1: 19-27. 
Golubović M, Balana I, Stanojević D. 1992. Melliferous value of sunflower cultivars and hybrids. Savetovanje o unapređenju uljarstva Jugoslavije 34-40 (in Serbian).

Goulson D, Nicholls E, Botías C, Rotheray EL. 2015. Bee declines driven by combined stress from parasites, pesticides, and lack of flowers. Science 6229: 1435-1444.

Jančić V, Pap J. 1980. Dependence of yield of sunflower hybrid seed on environmental factors and insects. In: Proc. 8th Int. Sunflower Conf, Minneapolis, Minnesota, USA, pp. 309-318.

Jevtić RT. 1955. Honey bee life and their farming. Zadružna knjiga, Beograd (in Serbian).

Jocić S. 2000. The degree of fertilization in sunflower hybrids in 1999. Zbornik radova Instituta za ratarstvo i povrtarstvo 33 : 81-90.

Joksimović J, Atlagić J, Sakač Z, Miklič V, Dušanić N. 2003. Phenotypic and genotypic variability of disc flower corolla length and nectar content in sunflower. Genetika 35: 131-138.

Joksimović J, Atlagić J, Miklič V, Dušanić N, Sakač Z. 2005. Interrelationship of pollination conditions, fertilization and sunflower seed yield. Genetika 37: 209-215.

Leclercq P. 1966. Une sterilite male cytoplasmique chez la tournesol. Ann Amelior Plant 19: 99-106.

Lyakh V, Totsky I. 2014. Selective elimination of gametes during pollen storage at low temperature as a way to improve the genetic structure of sporophytic population for cold tolerance. Helia 37 : 227-235.

Marinković R, Škorić D. 1986. The percentage of fertilization and self-fertility in some sunflower inbred lines and their F1 hybrids. Zbornik radova sa savetovanja o unapređenju uljarstva Jugoslavije 27-37 (in Serbian).

McKenna MA, Thomson JD. 1988. A technique for sampling and measuring small amounts of floral nectar. Ecology 69: 1306-1307.

Mesquida J, Marilleau R, Pham-Delegue M. 1988. A study of rapeseed (Brassica napus L. var. oleifera metzger) flower nectar secretions. Apidologie 19: 307-318.

Miklič V. 1992. The influence of climatic factors and genotypes on sunflower pollinators visit. Zbornik radova Instituta za ratarstvo $i$ povrtarstvo 20: 449-457 (in Serbian).

Miklič V. 1996. The effect of different genotypes and individual climate factors on the visit of honey bees and other pollinators and fertilization of sunflower. Masters Thesis, Faculty of Agriculture, University of Novi Sad (in Serbian).

Miklič V, Dušanič N, Joksimovič J. 2000a. Limiting factors in the production of sunflower seed in 1999. Zbornik naučnih radova Instituta PKB Agroekonomik 6: 107-15 (in Serbian).

Miklič V, Atlagić J, Sakač Z, Dušanić N, Joksimović J, Mihajlović D. 2000 b. Effects of genotype and growing conditions on several parameters of sunflower attractiveness to bees. Zbornik radova Instituta za ratarstvo i povrtarstvo 38: 181-192 (in Serbian).

Miklič V, Dušanić N, Atlagić J, et al. 2002. Effects of genotype, fertilization and microclimate on visitation by pollinators and yield of sunflower. Zbornik radova Instituta za ratarstvo $i$ povrtarstvo 36: 179-188 (in Serbian).

Miklič V, Atlagić J, Sakač Z, Dušanić N, Joksimović J, Mihailović D. 2003. The effect of genotype and growing conditions on some parameters of attractiveness for bees. Zbornik radova Instituta za ratarstvo i povrtarstvo 38: 181-192 (in Serbian).

Pham-Delegue MH, Masson C, Bonjean A, Etievant P, Marilleau R. 1985. Étude des paramètres chimiques impliqués dans la pollinisation du tournesol par les abeilles en production de semences hybrides. In: Proc. of the 11th Inter. Sunf. Conf., 10-13 March, Mar Del Plata, Argentina, pp. 559-564.

Plavša N, Nedić N. 2015. Practicum in beekeeping. Novi Sad: Faculty of Agriculture, pp. 1-153 (in Serbian).

Putt ED. 1940. Observations on morphological characters and flowering processes in sunflower (Helianthus annuus L.). Sci Agric 25: 185-190.

Sakač Z, Terzić S, Miklič V. 2008. The appropriate technique for collecting and measuring the amount of floral nectar in sunflower (Helianthus annuus L.). Book of abstracts, 17th International Sunflower Conference, June 8-12, Cordoba, Spain.

Sammataro D, Erickson EH, Garment MB. 1983. Intervarietal structural differences of sunflower (Helianthus annuus) florets their importance to honey bee visitation. In: Proc. 5th Sunflower Res. Workshop, Minot, ND. Natl. Sunflower Assoc., Bismarck, $N D$.

Shein SE, Sargent SJ, Miko J. 1980. An evaluation of differential attractivenness of sunflower genotypes to honey bees. In: Proc. 9th Int. Sunflower Conf., Torremolinos, Spain, 8-13 June. Int. Sunflower Assoc., Paris, France, pp. 216-220.

Škorić D, Vrebalov T, Ćupina T, et al. 1989. Sunflower (Monograph, in Serbian). Beograd: Nolit, pp. 1-635.

Smith DL. 1978. Planting seed production. In: Carter JF, ed. Sunflower science and technology. Madison, WI: Agron. Monogr. 19. ASA, CSSA, and SSSA, pp. 371-386.

Terzić S, Atlagić J, Miklič V, Jocić S, Sakač Z. 2008. Influence of pollination method, pollen viability and nectar content on the sunflower seed yield. Zbornik abstrakata petog naučno-stručnog simpozijuma iz selekcije i semenarstva društva selekcionera i semenara. Vrnjačka Banja, 25-28 maj, p. 49 (in Serbian).

Terzić S, Miklič V, Atlagić J, Jocić S, Marjanović-Jeromela A, Dedić B. 2010a. Bumble bee cost-effectiveness for sunflower pollination in isolation cages. Agric Econ 57: 190-196.

Terzić S, Milovac Ž, Miklič V, et al. 2010b. The impact of treatment of sunflower seeds with insecticides on visit of pollinators and harmfull insects. Selekcija i semenarstvo 16: 17-24 (in Serbian).

Vear F, Pham-Delegue M, Tourvieille de Labrouhe D, et al. 1990. Genetical studies of nectar and pollen production in sunflower. Agronomie 10: 219-231.

Waddington KD, Herbst LH. 1987. Body Size and the Functional Length of the Proboscis of Honey Bees. Fla Entomol 70: 124-128.

Cite this article as: Terzić S, Miklič V, Čanak P. 2017. Review of 40 years of research carried out in Serbia on sunflower pollination. OCL 24(6): D608. 